\title{
DIVERSITY OF ENDOPHYTIC FUNGI ASSOCIATED WITH FRUITS AND LEAVES OF TAMARIND (Tamarindus indica L.) BASED ON ITS RIBOSOMAL DNA SEQUENCES
}

\author{
NURUL ASYIQIN MOHD ZAINI ${ }^{1}$, NURUL HUWAIDAH MD NIZAM, \\ DAYANG FATIN ZAFIRA AWG ZAINAL ABIDIN, NOR IZANIS AZNI MOHD NAZRI AND \\ NUR AIN IZZATI MOHD ZAINUDIN*
}

Department of Biology, Faculty of Science, Universiti Putra Malaysia, 43400 Serdang, Selangor, Malaysia

Received 18 February 2020 /Accepted 2 May 2020

\begin{abstract}
Plant-associated microbes are among essential natural resources that abundantly exist in a natural environment, such as endophytic fungi. Studies on endophytic fungi in medicinal plants have allowed the discovery of numerous fungi species and their hidden potentials. Therefore, this study focused on the isolation and identification of endophytic fungi from several plant parts of tamarind ( $T$. indica), such as leaves and fruits. A total of 69 fungal cultures were successfully isolated and identified into 31 distinct species from 15 genera based on morphological characteristics and internal transcribed spacer (ITS) sequence analysis using a Maximum Likelihood method. A high diversity of endophytic fungi associated with T. indica were observed by ShannonWiener index $\mathrm{H}^{\prime}$ (3.083). There were six different species obtained from the genus Colletotrichum (C. aenigma, C. brevisporum, C. cobbittiense, C. fructicola, C. gloeosporioides and C. siamense), and Diaporthe (D. arecae, D. ceratozamiae, D. phaseolorum, D. pseudomangiferae, D. psendooculi and D. pseudophoenicicola), four species of Aspergillus (A. aculeatus, A. carbonarius, A. flavus and A. tubingensis), two species of Curvularia/Cocbliobolus (C. geniculatus and C. lunata) and Nigrospora (N. lacticolonia and N. oryzae), two species of Lasiodiplodia ( L. pseudotheobromae and L. theobromae) and Penicillium (P. rolfsii and P. verruculosum). Other fungal species that were also identified are Botryosphaeria mamane, Fusarium solani, Truncospora tepbropora, Phyllosticta fallopiae, Sarcostroma bisetulatum, Trichoderma asperellum and Xylaria feejeensis.
\end{abstract}

Keywords: Endophytic fungi, internal transcribed spacer (ITS), phylogenetic tree, tamarind

\section{INTRODUCTION}

Endophytic fungi are microorganisms inhabiting plant tissues in a part of their life without showing any harm toward the host plants. The species of endophytic fungi are expected in over a million species, which arisen from the natural surroundings (Mishra et al. 2018). They are widely distributed, which have been found in many plant species that can grow in natural environments such as terrestrial plant communities (Nisa et al. 2015). Endophytic fungi such as Aspergillus, Colletotrichum, Fusarium, Penicillium and Trichoderma may colonize several parts of plants, including fruits and leaves

\footnotetext{
"Corresponding author, email: ainizzati@upm.edu.my
}

(Hanada et al. 2010). There are many research studies reported the abundance of fungi associated with plants, however, there is a lack of study in the endophytic fungi associated with T. indica.

Bourou et al. (2010) reported, three genera of arbuscular mycorrhizal fungi (Acaulospora, Glomus and Scutellospora) were associated with T. indica. Tamarind tree has been reported to be infected by some wood decay fungi such as Daldinia concentrica, Schizophyllum commune, Flavodon flavus, Irpex bydnoides, and Phellinus fastuosus (Nnagadesi \& Arya 2015). In previous reports, Aspergillus niger, Rhizopus stolonifer, Ulocladium chartarum, Penicillium chrysogenum, P. citrinum and Phomopsis liquidambaris were associated with infected-tamarind fruit 
(Danggomen et al. 2013; Peter \& Patrick 2017). Penicillium chrysogenum and $P$. citrinum are confirmed pathogens and caused spoilage in fruits (Peter \& Patrick 2017). Recently, Aspergillus niger has been proven as a pathogen that causes black pod of tamarind (Meena et al. 2018).

Due to the information regarding endophytic fungal diversity associated with $T$. indica is lacking, this study will provide important information regarding the diversity of fungal endophytes associated with T. indica. This study was aimed to determine the culturable endophytic fungal diversity associated with T. indica using molecular phylogenetic analysis of ITS rDNA sequences.

\section{MATERIALS AND METHODS}

\section{Plant Samples}

Collection of leaves and fruits samples of T. indica was completed in 2018 and 2019 at Jalan Asam Jawa, Universiti Putra Malaysia, Serdang Selangor located at $3^{\circ} 00^{\prime} 09.0^{\prime \prime} \mathrm{N}$ $101^{\circ} 42^{\prime} 34.8^{\prime \prime} \mathrm{E}$ (Fig. 1). The fruits and leaves samples were collected using fruit picker from 20 T. indica trees with $2 \mathrm{~m}$ apart. All samples were further placed in paper bags, properly labeled, and brought to the Mycology Laboratory, Department of Biology for fungal isolation.

\section{Isolation, Purification and Preservation of Microfungi}

All plant samples were washed in running tap water for $30 \mathrm{~min}$ to remove any debris or soil before being processed. The leaves were cut into segments of $5 \times 5 \mathrm{~mm}$. Then, the surface of the leaves and fruits was surface sterilized by following the method described by Ravindran et al. (2012) by immersing in 70\% ethanol $(5 \mathrm{sec}), 4 \%$ sodium hypochlorite $(\mathrm{NaOCl})$ (90 sec), rinsed with sterile distilled water $(30 \mathrm{sec})$ and blotted dry with sterile filter paper. All of the segments were placed (3 segments each plate) on potato dextrose agar (PDA) supplemented with streptomycin $(0.05 \mathrm{~g} / \mathrm{ml})$ and neomycin (0.01 g/L) using sterilized forceps. The culture plate was incubated at room temperature $\left(27 \pm 2^{\circ} \mathrm{C}\right)$ for 5 to 7 days or until there was an appearance of mycelium or colony from the sample fragments.

The fungal mycelia grown from the parts of the sample were streaked on $4 \%$ water agar (WA) for purification. The WA plate was incubated for another 24 hours. Then, the single tip of hyphae was cut and transferred onto a new PDA plate and incubated at $27 \pm 2^{\circ} \mathrm{C}$ for seven days. The pure isolated fungi were preliminarily identified by examining their morphological characteristics. All isolates were maintained and preserved at $-20{ }^{\circ} \mathrm{C}$ using a modified filter paper method for working and stock cultures with slight modifications (Fong et al. 2000).
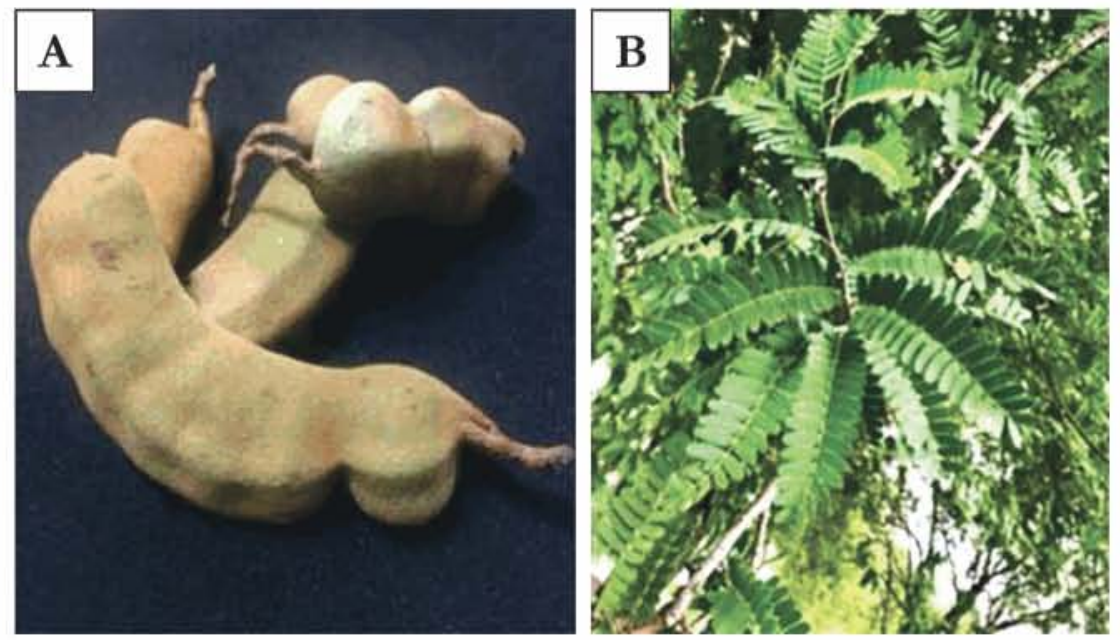

Figure 1 Samples of fruits (A) and leaves (B) of T. indica were collected in Persiaran Asam Jawa, Universiti Putra Malaysia 

DNA Extraction, PCR Amplification and
Sequencing

All isolates were cultured on PDA and incubated for 5 days. DNA of the isolates was extracted using UltraClean ${ }^{\circledR}$ Microbial DNA Isolation Kit (MO BIO, Carlsbad, CA, USA) according to manufacturer's instruction. Amplification of the ITS regions was conducted using Polymerase Chain Reaction (PCR) machine (Hercuvan Lab Systems, California, USA) involved primers ITS1 (5'TCCGTAGGTGAACCTGCGG-3') and ITS4 (5'-TCCTCCGCTTATTGATATGC-3') (White et al. 1990). The PCR master mix was prepared from $4 \mu \mathrm{L}$ of $5 \times \mathrm{PCR}$ buffer, $2 \mu \mathrm{L}$ of $2 \mathrm{mM}$ dNTP, $2 \mu \mathrm{L}$ of $25 \mathrm{mM} \mathrm{MgCl}, 1 \mu \mathrm{L}$ of $10 \mathrm{mM}$ for each primer, $0.1 \mu \mathrm{L}$ of Taq DNA polymerase with concentration $5 \mathrm{U} \mu \mathrm{L}, 6.9 \mu \mathrm{L}$ of nucleasefree water and $3 \mu \mathrm{L}$ of DNA in a total volume of $20 \mu \mathrm{L}$. The PCR protocol with initial denaturation step was done for $30 \mathrm{sec}$ at $95^{\circ} \mathrm{C}$, followed by 35 cycles of denaturation $\left(95^{\circ} \mathrm{C}\right.$ for $10 \mathrm{sec})$, annealing $\left(59{ }^{\circ} \mathrm{C}\right.$ for $\left.15 \mathrm{sec}\right)$ and extension $\left(72^{\circ} \mathrm{C}\right.$ for $\left.30 \mathrm{sec}\right)$, and was completed by final extension step at $72{ }^{\circ} \mathrm{C}$ for $5 \mathrm{~min}$. Then, the PCR product was prepared for gel electrophoresis or stored at $-20^{\circ} \mathrm{C}$.

The PCR products were gel-electrophoresed using $1.5 \%$ agarose gel. The mixture of $2.5 \mu \mathrm{L}$ of $6 \times$ loading dye (blue/orange) and $2.5 \mu \mathrm{L}$ of $100 \mathrm{bp}$ DNA marker were used as a ladder. The DNA and ladder were pipetted with $5 \mu \mathrm{l}$ in volume into the holes using a micropipette and electrophoresed. The amplicon size was visualized under a UV trans-illuminator. The PCR products were purified using a QIAquick gel extraction kit (QIAGEN, USA), following the manufacturer's instructions. The purified PCR products were sequenced by using an Applied Biosystem 3730xl DNA Analyzer (MyTACG Bioscience Company, MY).

\section{Phylogenetic Analysis}

Evolutionary analyses of ITS sequences were conducted in Molecular Evolutionary Genetics Analysis (MEGA) 6.0 software to obtain alignment sequences (Tamura et al. 2013).
Homologous sequences were obtained from The GenBank database NCBI (http://blast. ncbi.nlm.nih.gov/) using BLASTN search (https://blast.ncbi.nlm.nih.gov/Blast.cgi? PAGE_TYPE=BlastSearch) of the ITS sequences. The phylogenetic analysis was conducted using the Maximum Likelihood method based on the Tamura-Nei model with 1000 bootstrap test (Tamura \& Nei 1993) in MEGA version 6.0. Saccharomyces cerevisae CBS 1171 (AB018043) was used as an outgroup (Fig. 3). The GenBank accession number of new sequences were listed in Table 1.

\section{Species Diversity}

The species diversity was calculated by using the Shannon-Weiner Index (Spellerberg 2008) as formula below:

$$
H^{\prime}=-\sum_{t=1}^{s} p i \ln p i
$$

where:

$H^{\prime}=$ Value of Shannon Wiener's diversity index

$p i=$ Proportion of species

$s \quad=$ Number of species in community

$I=$ Number of individuals in species

\section{RESULTS AND DISCUSSION}

A total of 69 isolates of fungi were obtained from 20 fruit and leaf samples of $T$. indica, and were identified based on their morphological characteristics (Fig. 2) and ITS sequence analysis (Table 1 and Fig. 2). Thirty-two species belong to 15 genera were found in the present study including Aspergillus (4 species), Botryosphaeria (a single species), Colletotrichum (6 species), Cocbliobolus/Curvularia (2 species), Diaporthe (6 species), Fusarium (a single species), Lasiodiplodia (2 species), Nigrospora (2 species), Penicillium (2 species), Truncospora (a single species), Pbyllosticta (a single species), Sarcostroma (a single species), Trichoderma (a single species), and Xylaria (a single species) (Table 1). 

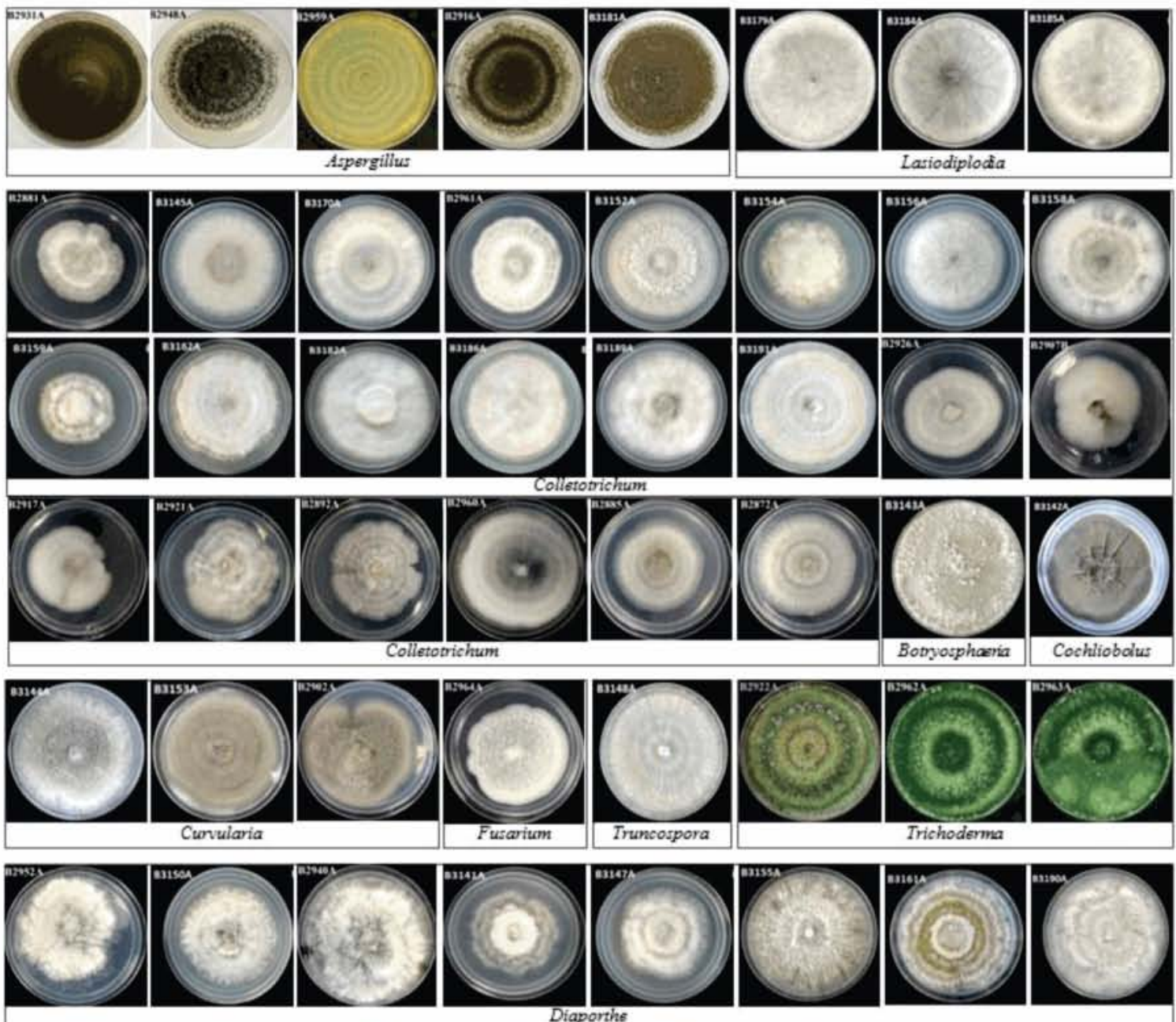

Trichoderma
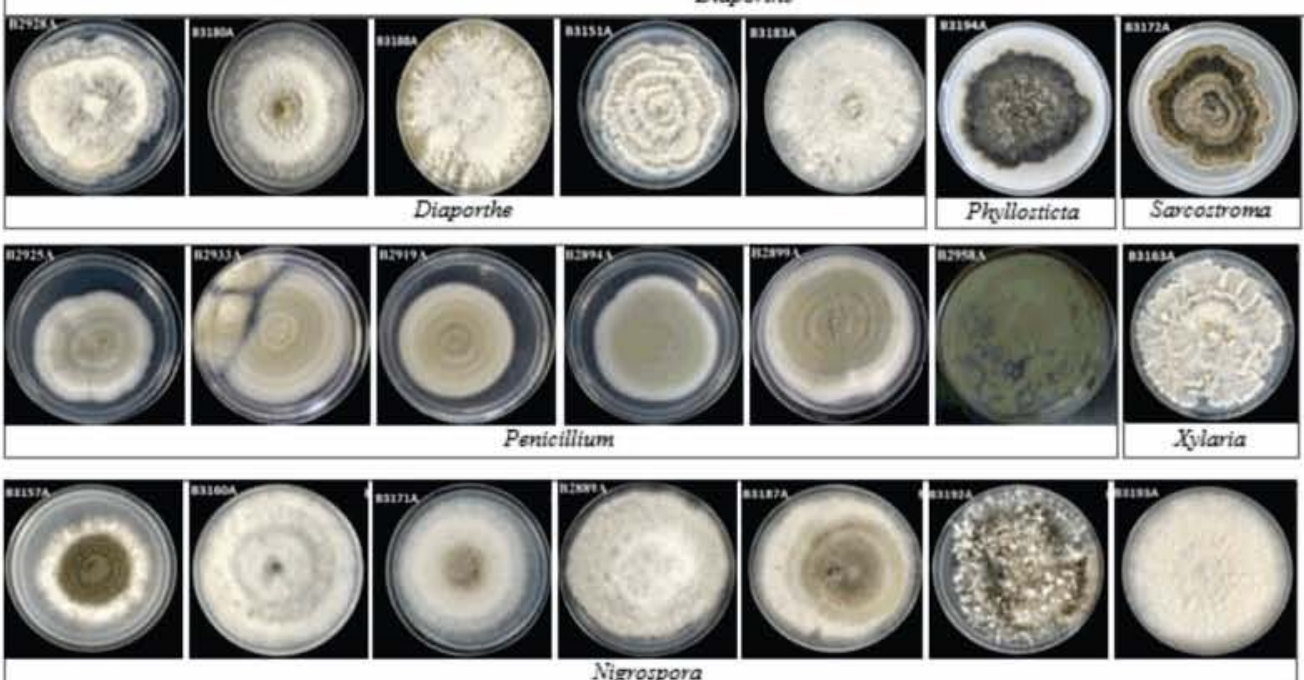

Figure 2 Fungal morphological retrieved in the culture media isolation procedure. Endophytic fungi were isolated from fruits and leaves of $T$. indica. Fungi were cultivated in PDA medium at $27{ }^{\circ} \mathrm{C}$ for 7 days

Based on phylogenetic analysis of ITS sequences of the 69 endophytic fungi isolated from tamarind fruits and leaves, two major clades (A and B) were generated (Fig. 3). The first clade (Clade A) comprises isolates of fungi under Phylum Ascomycota and Clade B contains Truncospora tephropora B3148 (Phylum
Basidiomycota). Clade A was divided into 2 subclades; Clade A1 represents isolates of Aspergillus, Botryoshaeria, Colletotrichum, Diaporthe, Fusarium, Nigrospora, Sarcostroma, Trichoderma, Penicillium, Phyllosticta, and Xylaria, whereas Clade A2 represents isolates of Lasiodiplodia and Curvularia/Cochliobolus. 
Table 1 ITS sequences GenBank accession number of deposited fungal isolates from fruits and leaves of T. indica

\begin{tabular}{|c|c|c|c|c|}
\hline No. & Isolates & Species & Plant part & GenBank accession number \\
\hline 1. & B2931 & Aspergillus aculeatus & Fruit & MK204304 \\
\hline 2. & B2948 & A. carbonarius & Fruit & MK204302 \\
\hline 3. & B2959 & A. flavus & Fruit & MK204299 \\
\hline 4. & B2916 & A. tubingensis & Fruit & MK204311 \\
\hline 5. & B3181 & A. tubingensis & Leaf & MT043791 \\
\hline 6. & B3143 & Botryosphaeria mamane & Leaf & MT043767 \\
\hline 7. & B2881 & Colletotrichum aenigma & Leaf & MK204314 \\
\hline 8. & B3145 & C. brevisporum & Leaf & MT043769 \\
\hline 9. & B 3170 & C. cobbittiense & Leaf & MT043786 \\
\hline 10. & B2961 & C. fructicola & Leaf & MK204289 \\
\hline 11. & B3152 & C. gloeosporioides & Leaf & MT043774 \\
\hline 12. & B3154 & C. gloeosporioides & Leaf & MT043776 \\
\hline 13. & B3156 & C. gloeosporioides & Leaf & MT043778 \\
\hline 14. & B3158 & C. gloeosporioides & Leaf & MT043780 \\
\hline 15. & B3159 & C. gloeosporioides & Leaf & MT043781 \\
\hline 16. & B3162 & C. gloeosporioides & Leaf & MT043784 \\
\hline 17. & B3182 & C. gloeosporioides & Leaf & MT043792 \\
\hline 18. & B3186 & C. gloeosporioides & Leaf & MT043796 \\
\hline 19. & B3189 & C. gloeosporioides & Leaf & MT043799 \\
\hline 20. & B3191 & C. gloeosporioides & Leaf & MT043801 \\
\hline 21. & B2926 & C. siamense & Fruit & MK204291 \\
\hline 22. & B2907 & C. siamense & Fruit & MK204292 \\
\hline 23. & B2917 & C. siamense & Fruit & MK204293 \\
\hline 24. & B2921 & C. siamense & Fruit & MK204294 \\
\hline 25. & B2892 & C. siamense & Leaf & MK204295 \\
\hline 26. & B2960 & C. siamense & Leaf & MK204296 \\
\hline 27. & B2885 & C. siamense & Leaf & MK204297 \\
\hline 28. & B2872 & C. siamense & Leaf & MK204298 \\
\hline 29. & B3144 & Curvularia lunata & Leaf & MT043768 \\
\hline 30. & B3153 & C. Iunata & Leaf & MT043775 \\
\hline 31. & B3142 & Cocbliobolus geniculatus & Leaf & MT043766 \\
\hline 32. & B2902 & C. Innata & Leaf & MK204312 \\
\hline 33. & B2952 & Diaporthe arecae & Fruit & MK204301 \\
\hline 34. & B3150 & D. ceratozamiae & Leaf & MT043772 \\
\hline 35. & B2940 & D. phaseolorum & Fruit & MK204303 \\
\hline 36. & B3141 & D. phaseolorum & Leaf & MT043765 \\
\hline 37. & B3147 & D. pbaseolorum & Leaf & MT043770 \\
\hline 38. & B3155 & D. phaseolorum & Leaf & MT043777 \\
\hline 39. & B3161 & D. phaseolorum & Leaf & MT043783 \\
\hline 40. & B3190 & D. phaseolorum & Leaf & MT043800 \\
\hline 41. & B2928 & D. pseudomangiferae & Fruit & MK204305 \\
\hline 42. & B3180 & D. pseudooculi & Leaf & MT043790 \\
\hline 43. & B3188 & D. psendooculi & Leaf & MT043798 \\
\hline 44. & B3151 & D. pseudopboenicicola & Leaf & MT043773 \\
\hline 45. & B3183 & D. pseudopboenicicola & Leaf & MT043793 \\
\hline 46. & B2964 & Fusarium solani & Fruit & MK204285 \\
\hline 47. & B3184 & Lasiodiplodia pseudotheobromae & Leaf & MT043794 \\
\hline 48. & B3179 & L. theobromae & Leaf & MT043789 \\
\hline 49. & B3185 & L. theobromae & Leaf & MT043795 \\
\hline 50. & B3157 & Nigrospora lacticolonia & Leaf & MT043779 \\
\hline 51. & B3160 & N. lacticolonia & Leaf & MT043782 \\
\hline 52. & B3171 & N. Lacticolonia & Leaf & MT043787 \\
\hline 53. & B2889 & N. oryzae & Leaf & MK204313 \\
\hline 54. & B3187 & N. oryzae & Leaf & MT043797 \\
\hline 55. & B3192 & N. oryzae & Leaf & MT043802 \\
\hline 56. & B3193 & N. oryzae & Leaf & MT043803 \\
\hline 57. & B2925 & Penicillium rolfsii & Fruit & MK204306 \\
\hline 58. & B2933 & P. rolfsii & Fruit & MK204307 \\
\hline 59. & B2919 & P. rolfsii & Fruit & MK204308 \\
\hline 60. & B2894 & P. rolfsii & Leaf & MK204309 \\
\hline 61. & B2899 & P. rolfsii & Leaf & MK204310 \\
\hline 62. & B2958 & P. verruculosum & Fruit & MK204300 \\
\hline 63. & B3194 & Phyllosticta fallopiae & Leaf & MT043804 \\
\hline 64. & B 3172 & Sarcostroma bisetulatum & Leaf & MT043788 \\
\hline 65. & B2922 & Tricboderma asperellum & Fruit & MK204286 \\
\hline 66. & B2962 & T. asperellum & Fruit & MK204287 \\
\hline 67. & B2963 & T. asperellum & Fruit & MK204288 \\
\hline 68. & B3148 & Truncospora tepbropora & Leaf & MT043771 \\
\hline 69. & B3163 & Xylaria feejeensis & Leaf & MT043785 \\
\hline
\end{tabular}




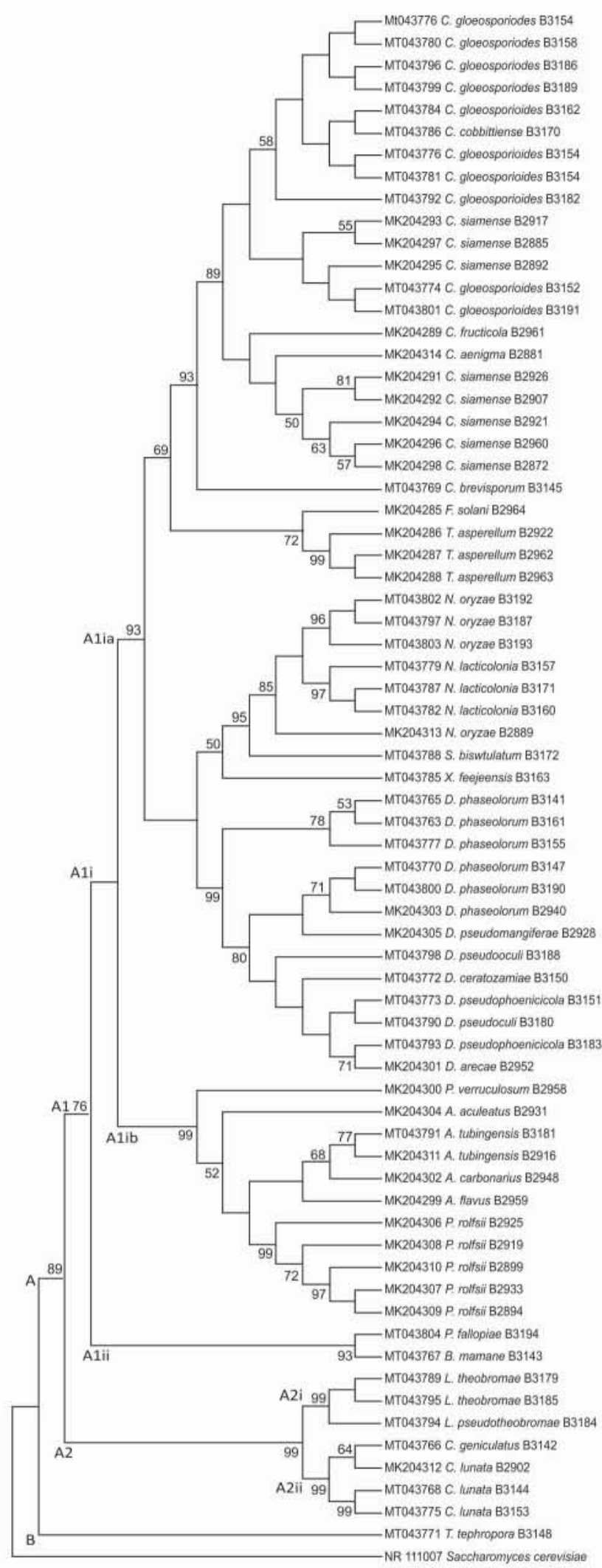

Figure 3 Phylogenetic tree generated from the Maximum Likelihood method based on the ITS sequences of 69 fungal endophytes sequences associated with T. indica. The tree generated using Tamura-Nei model with 1000 Bootstrap replications. All Bootstrap scores with less than $50 \%$ are not shown in the tree

The Shannon index $\left(\mathrm{H}^{\prime}=3.083\right)$ indicated that the tamarind fungal community possesses a vast diversity of endophytic fungi (Table 2). The most diverse fungal genera isolated from tamarind leaves was Colletotrichum and Diaporthe (Fig. 3, Table 1). 
Table 2 Endophytic fungal percentage and Shannon-Wiener Index obtained from culture media isolation using fruits and leaves of T. indica

\begin{tabular}{|c|c|c|c|c|}
\hline No. & Species & Number of isolate & Percentage $(\%)$ & Shannon-Wiener Index $\left(\mathrm{H}^{\prime}\right)$ \\
\hline 1. & Aspergillus aculeatus & 1 & 1.45 & 0.061 \\
\hline 2. & A. carbonarius & 1 & 1.45 & 0.061 \\
\hline 3. & A. flavus & 1 & 1.45 & 0.061 \\
\hline 4. & A. tubingensis & 2 & 2.90 & 0.103 \\
\hline 5. & Botryosphaeria mamane & 1 & 1.45 & 0.061 \\
\hline 6. & Colletotricbum aenigma & 1 & 1.45 & 0.061 \\
\hline 7. & C. brevisporum & 1 & 1.45 & 0.061 \\
\hline 8. & C. cobbittiense & 1 & 1.45 & 0.061 \\
\hline 9. & C. fructicola & 1 & 1.45 & 0.061 \\
\hline 10. & C. gloeosporioides & 10 & 14.49 & 0.280 \\
\hline 11. & C. siamense & 8 & 11.59 & 0.250 \\
\hline 12. & C. lunata & 3 & 4.35 & 0.061 \\
\hline 13. & Cochliobolus geniculatus & 1 & 1.45 & 0.136 \\
\hline 14. & Diaportbe arecae & 1 & 1.45 & 0.061 \\
\hline 15. & D. ceratozamiae & 1 & 1.45 & 0.061 \\
\hline 16. & D. phaseolorum & 6 & 8.70 & 0.212 \\
\hline 17. & D. pseudomangiferae & 1 & 1.45 & 0.061 \\
\hline 18. & D. pseudooculi & 2 & 2.90 & 0.103 \\
\hline 19. & D. pseudophoenicicola & 2 & 2.90 & 0.103 \\
\hline 20. & Fusarium solani & 1 & 1.45 & 0.061 \\
\hline 21. & Lasiodiplodia theobromae & 2 & 2.90 & 0.103 \\
\hline 22. & L. pseudotheobromae & 1 & 1.45 & 0.061 \\
\hline 23. & Nigrospora lacticolonia & 3 & 4.34 & 0.136 \\
\hline 24. & N. oryzae & 4 & 5.79 & 0.165 \\
\hline 25. & Penicillium rolfsii & 5 & 7.25 & 0.190 \\
\hline 26. & P. verruculosum & 1 & 1.45 & 0.061 \\
\hline 27. & Truncospora tephropora & 1 & 1.45 & 0.061 \\
\hline 28. & Pbyllosticta fallopiae & 1 & 1.45 & 0.061 \\
\hline 29. & Sarcostroma bisetulatum & 1 & 1.45 & 0.061 \\
\hline 30. & Trichoderma asperellum & 3 & 4.34 & 0.136 \\
\hline \multirow[t]{2}{*}{31.} & Xylaria feejeensis & 1 & 1.45 & 0.061 \\
\hline & Total & 69 & 100 & 3.083 \\
\hline
\end{tabular}

In this study, the most abundant fungal (26 isolates) species obtained from $T$. indica leaves was from genus Colletotrichum where 10 isolates were identified as C. gloeosporioides with $14.49 \%\left(H^{\prime}=0.280\right)$. Endophytic C. fructicola and $C$. siamense have been recovered from healthy Cymbopogon citratus (Manamgoda et al. 2013). Weir et al. (2012) stated that C. siamense is geographically diverse with a varied host range and is a common saprobe or endophyte. Colletotrichum species can be found abundantly forming its association with temperate plants and they are widely distributed in the tropical and subtropical areas (Cannon et al. 2012), but no report on associations with $T$. indica. A study by Boddy (2016) also reported that Colletotrichum species could be existed within plant tissues without causing any harm while it is in an inactive state. These studies showed that members of Colletotrichum exhibit a multiple life styles.

Six isolates of endophytic Diaporthe phaseolorum have been isolates from healthy fruits and leaves of $T$. indica. Diaporthe spp. are known to be existed symbiotically alongside plants as saprobic, endophytic or phytopathogenic (Udayanga et al. 2011; Tan et al. 2013; Gomzhina \& Gannibal 2018). According to González and Tello (2011), endophytic Diaporthe species are commonly isolated from several hosts in the temperate and tropical region. Research on Diaporthe species by Gomes et al. (2013) collected several species of Diaporthe from Vaccinium growing regions in Europe including $D$. phaseolorum and $D$. arecae. Diaporthe pseudomangiferae has been reported cause inflorescence rot, rachis, canker, and flower abortion of mango (Serrato-Diaz et al. 2014). 
Endophytic C. lunata and Cocbliobolus geniculatus (telemorph of C. geniculata) have been isolated from leaves of $T$. indica. Two distinct species from genus Lasidioplodia that were isolated from the leaves of tamarind were Lasidioplodia theobromae and Lasidioplodia pseudotheobromae with a similarity percentage of $99 \%$ and $97 \%$ respectively. Similar to Colletotrichum species, Curvularia/Cocbliobolus and Lasiodiplodia are well-known plant pathogens and can also be endophytes.

In this study, Aspergillus tubengensis was found associated with the $T$. indica leaves. This species was found to form an association with many plant species such as the mangrove plant, Sonora desert plant (Nadumane et al. 2016), and strawberry (Palmer et al. 2019). Previously, other species of Aspergillus which is Aspergillus niger was isolated from diseased-fruits of $T$. indica and caused black pod (Meena et al. 2018). Two species of Penicillium, P. rolfsii and P. verruculosum have been isolated from healthy fruits and leaves of T. indica. Penicillium spp. are common pathogens and caused spoilage in fruits (Peter \& Patrick 2017). The assemblage of endophytic fungi in healthy tissue of $T$. indica may indicate that some of the fungi are possible latent pathogens and some may saprophytic.

The other genus dominated the $T$. indica leaves was Nigrospora sp. Wang et al. (2017) claimed that Nigrospora sp. is a common in forming symbiosis with plants as pathogens, endophytes or saprophytes. Nigrospora sphaerica (synonym of $N$. oryzae) was found inhabiting numerous hosts such as the Zea, Andropogon and Cymbopogon as reported by Wang et al. (2017). Supaphon and Preedanon (2019) also claimed, the species was isolated from Helianthus annus as an endophyte. Botryosphaeria mamane was only one isolate obtained from this genus. According to Phillips et al. (2013), this species that belonged to the Botryosphaeriaceae is existed diversely in nature as pathogenic, endophytic or saprobic with more preferable to woody plants. A study by Li et al. (2018), also recorded the discovery of species of Botryosphaeriaceae from plantation trees including Cunninghamina lanceolata, Dimocarpus longan, Melastoma sanguineum and Phoenix hanceana, which were growing adjacent to Eucalyptus.
Phyllostica species have been known to form their association with plants widely and can be either pathogens or endophytes. In this study, one isolate of Phyllosticta fallopiae with a $100 \%$ percentage of similarity with the established sequence in the GenBank database. The morphology of the isolate characterized as P. fallopiae also fit the description of this species by Zhang et al. (2013). One isolate was identified as Xylaria feejeensis which was isolated from healthy leaves samples with $98.90 \%$ similarity to the GenBank sequences. According to Chen et al. (2013) xylariaceous fungi are dominantly associated with the Dendrobium species of class Orchidaceae. This finding had supported the existence of Xylaria sp. as an endophyte. Truncospora tephropora (synonym of Perenniporia tephropora) was the only basidiomycete found associated with healthy $T$. indica leaves with similarity percentage of $99.84 \%$ from the sequence from GenBank database.

\section{CONCLUSION}

This study revealed that various endophytic fungi were isolated from the fruits and leaves of tamarind. The 31 species that have been successfully identified were $A$. aculeatus, A. carbonarius, A. flavus, A. tubingensis, B. mamane, C. aenigma, C. brevisporum, C. cobbittiense, C. fructicola, C. gloeosporioides, C. siamense, C. geniculatus, C. lunata, D. arecae, D. ceratozamiae, D. phaseolorum, D. pseudomangiferae, D. pseudooculi, D. pseudophoenicicola, F. solani, L. pseudotheobromae, L. theobromae, N. lacticolonia, N. oryzae, P. rolfsii, $P$. verruculosum, $T$. tephropora, $P$. fallopiae, S. bisetulatum, T. asperellum and X. feejeensis.

\section{ACKNOWLEDGEMENTS}

The authors thank all staff of the Department of Biology, Faculty of Science, Universiti Putra Malaysia for their facilities during the study. This work was partially supported by the Fundamental Research Grant Scheme (FRGS/1/2018/STG03/UPM/02/12/ 5540129). 


\section{REFERENCES}

Boddy L. 2016. Fungi, ecosystems, and global change. In The fungi (pp. 361-400). Oxford, London: Academic Press.

Bourou S, Ndiaye F, Diouf M, Diop T, Damme PV. 2010. Tamarind (Tamarindus indica L.) parkland mycorrhizal potential within three agro-ecological zones of Senegal. Fruits 65(6):377-385.

Cannon PF, Damm U, Johnston PR, Weir BS. 2012. Colletotrichum-current status and future directions. Stud Mycol 73: 181-213.

Chen J, Zhang LC, Xing YM, Wang YQ, Xing XK, Zhang DW, Liang HQ, Guo SX. 2013. Diversity and taxonomy of endophytic Xylariaceous fungi from medicinal plants of Dendrobium (Orchidaceae). PLoS One 8(3):e58268.

Danggomen A, Visarathanonth N, Manoch L, Piasai O. 2013. Morphological studies of endophytic and plant pathogenic Phomopsis liquidambaris and Diaporthe phaseolorum ( $P$. phaseoli anamorph) from healthy plants and diseased fruits. Thai J Agri Sci 46(3):157-64.

Fong YK, Anuar S, Lim HP, Tham FY, Sanderson FR. 2000. A modified filter paper technique for longterm preservation of some fungal cultures. Mycologist 14:121-30.

Gomes RR, Glienke C, Videira SIR, Lombard L, Groenewald JZ, Crous PW. 2013. Diaporthe: a genus of endophytic, saprobic and plant pathogenic fungi. Persoonia 31(1):1-41.

Gomzhina MM, Gannibal PB. 2018. First report of the fungus Diaporthe phaseolorum on sunflower in Russia. Microbiol Independent Res J 5(1), 65-70.

González V, Tello ML. 2011. The endophytic mycota associated with Vitis vinifera in central Spain. Fungal Divers 47:29-42.

Hanada RE, Pomella AWV, Costa HS, Bezerra JL, Loguercio LL, Pereira JO. 2010. Endophytic fungal diversity in Thebroma cacao (cacao) and Theobroma grandiflorum (cupuacu) trees and their potential for growth promotion and biocontrol of black-pod disease. Fungal Biol 114:901-10.

Li GQ, Liu FF, Li JQ, Liu QL, Chen SF. 2018. Botryosphaeriaceae from Eucalyptus plantations and adjacent plants in China. Persoonia 40:63-95.

Manamgoda DS, Udayanga D, Cai L, Chukeatirote E, Hyde KD. 2013. Endophytic Colletotrichum from tropical grasses with a new species $C$. endophytica. Fungal Divers 61(1):107-15.

Meena C, Bhatnagar P, Meena RR, Prahlad VC, Kumar A. 2018. First report of black pod in tamarind due to Aspergillus niger from India. Int J Curr Microbiol Appl Sci 7(4):1127-30.
Mishra Y, Singh A, Batra A, Sharma MM. 2014. Understanding the biodiversity and biological applications of endophytic fungi: A Review. J Microb Biochem Technol S8: 004. doi:10.4172/1948-5948.S8-004

Nadumane VK, Venkatachalam P, Gajaraj B. 2016. Aspergillus applications in cancer research. In: New and Future Developments in Microbial Biotechnology and Bioengineering (pp. 243-55). Elsevier.

Nisa H, Kamili AN, Nawchoo LA, Shafi S, Shameem N, Bandh SA. 2015. Fungal endophytes as prolific source of phytochemicals and other bioactive natural products: A review. Microb Pathog 82: 50-9.

Nnagadesi PK, Arya A. 2015. Wood decay fungi associated with tamarind tree in Gujarat, India. Int Lett Nat Sci 46:84-91.

Palmer MG, Mansouripour SM, Blauer KA, Holmes GJ. 2019. First report of Aspergillus tubingensis causing strawberry fruit rot in California. Plant Dis 103(11):2948.

Peter WS, Patrick, OH. 2017. Identification of fungal species associated with contaminants and pathogenicity on Tamarindus indica fruits from Maiduguri Monday Market, Borneo State Nigeria. Plant 5(2):36-41.

Phillips AJL, Alves A, Abdollahzadeh J, Slippers B, Wingfield MJ, Groenewald JZ, Crous PW 2013. The Botryosphaeriaceae: genera and species known from culture. Stud Mycol 76:51-167.

Ravindran C, Naveenan T, Varatharajan GR, Rajasabapathy R, Meena RM. 2012. Antioxidants in mangrove plants and endophytic fungal associations. Bot Mar 55:269-79.

Sabra M, Aboulnasr A, Franken P, Perreca E, Wright LP, Camehl I. 2018. Beneficial root endophytic fungi increase growth and quality parameters of sweet basil in heavy metal contaminated soil. Front Plant Sci 8:1726.

Serrato-Diaz LM, Rivera-Vargas LI, French-Monar RD. 2014. First report of Diaporthe pseudomangiferae causing inflorescence rot, rachis, canker, and flower abortion of mango. Plant Dis 98(7):1004-5.

Spellerberg IF. 2008. Encyclopedia of Ecology. Lincoln (NZ): Lincoln University. p.3249-52.

Supaphon P, Preedanon S. 2019. Evaluation of in vitro alpha-glucosidase inhibitory, antimicrobial, and cytotoxic activities of secondary metabolites from the endophytic fungus, Nigrospora sphaerica, isolated from Helianthus annuus. Ann Microbiol 69:1397406.

Tamura K, Nei M. 1993. Estimation of the number of nucleotide substitutions in the control region of mitochondrial DNA in humans and chimpanzees. Mol Biol Evol 10:512-26. 
Tamura K, Stecher G, Peterson D, Filipski A, Kumar S. 2013. MEGA6: Molecular Evolutionary Genetics Analysis version 6.0. Mol Biol Evol 30:2725-9.

Tan YP, Edwards J, Grice KRE, Shivas RG. 2013. Molecular phylogenetic analysis reveals six new species of Diaporthe from Australia. Fungal Divers 61(1):251-60.

Udayanga D, Xingzhong L, McKenzie EHC, Chukeatirote E, Bahkali AHA, Hyde KD. 2011. The genus Phomopsis: biology, applications, species concepts and names of common pathogens. Fungal Divers 50:189-225.

Wang M, Liu F, Crous PW, Cai L. 2017. Phylogenetic reassessment of Nigrospora: ubiquitous endophytes, plant and human pathogens. Persoonia 39:118.
Weir B, Johnston PR, Damm U. 2012. The Colletotrichum gloeosporioides species complex. Stud Mycol 73:115-80.

White TJ, Burns T, Lee S, Taylor J. 1990. Amplification and direct sequencing of fungal ribosomal RNA genes for phylogenetics. In $\mathrm{M}$ A Innis, $\mathrm{D} \mathrm{H}$ Gelfand, J J Sninsky and T J White (eds.). PCR protocols: A guide methods and applications. San Diego: Academic Press, 315-22.

Xia Y Sahib MR, Amna A, Opiyo SO, Zhao Z, Gao YG. 2019. Culturable endophytic fungal communities associated with plants in organic and conventional farming systems and their effects on plant growth. Sci Rep 9:1669.

Zhang K, Su YY, Cai L. 2013. Morphological and phylogenetic characterisation of two new species of Phyllosticta from China. Mycol Prog 12:547-56. 